TAPROBANICA, ISSN 1800-427X. April, 2013. Vol. 05, No. 01: pp. 71-72.

(C) Taprobanica Private Limited, 146, Kendalanda, Homagama, Sri Lanka. www.taprobanica.org

\section{Rediscovery of Sonerila andamanensis Stapf \& King, 1900 (Melastomataceae)}

The type collection of Sonerila andamanensis Stapf \& King (in King, 1900) mentioned in the protologue (King's collector 48) from the Mt. Harriet Hills of South Andaman Island is presently not traceable at CAL and $\mathrm{K}$. However, another specimen of this species collected from the Andaman Islands in 1884 also by King's collector is deposited at Kew with the barcode accession no K000867666. This specimen was annotated as $S$. maculata Roxburgh in 1975 by Panighrahi from the Botanical Survey of India. A perusal of literature and herbarium survey has revealed that S. maculata has not been reported from Andaman-Nicobar Islands (Lakshminarasimhan \& Rao, 1996; Mathew, 1998; Pandey, \& Diwakar, 2008; VasudevaRao, 1986), and no literature or any other valid documentation are available showing $S$. andamanensis is a synonym of $S$. maculata (Lakshminarashimhan et. al. 2011).

Sonerila andamanensis was thought to be extinct and known only from the protologue (King, 1900) and the one and only specimen deposited at Kew. In 1976 this species was relocated on Saddle Peak (732m), the highest point in Andaman-Nicobar Archipelago. During an exploration carried out by the first author of this document in 1989, a tiny population of this species was located at its type locality after a lapse of approximately over 100 years. Recent exploration on Andaman Islands carried out by the first author in 2012 resulted in the discovery of a population flowering in Mt Harriet National Park at an altitude of about $365 \mathrm{~m}$ (Fig.1). Saddle Peak and Mount Harriet had already been declared as National Parks by the Andaman-Nicobar Forest Department and is a significant approach in the in-situ conservation of the species.

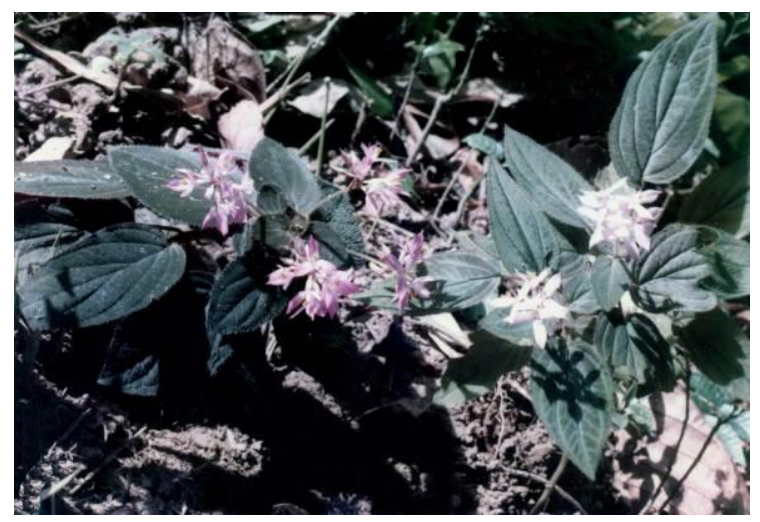

Figure 1: Sonerila andamanensis, two live specimens from Mt. Harriet, South Andaman.

\section{Sonerila andamanensis Stapf \& King, 1900}

Journal of the Asiatic Society of Bengal, 69 (1): 26, pl. 2. (1900).

Herbs 10-15 cm. Stem pubescent, pinkishbrown or greenish. Leaves $1.5-11.5$ x 1-5.5 $\mathrm{cm}$; petioles up to $5 \mathrm{~cm}$, pubescent; blades ovate to elliptic-ovate or lanceolate, pubescent, acute or shortly acuminate at apex, cordate or oblique at base, ciliate at margin, dark green or pinkish green above, green or pinkish below; lateral nerves up to 9 pairs. Flowers in axillary or terminal helicoid cymes, pale white or pinkish, many flowered; calyx lobes $c .0 .3 \mathrm{~cm}$, broadly triangular; petals $c .0 .5 \mathrm{~cm}$, elliptic to elliptic-lanceolate, pinkish or pale white; stamens 3 with ovate-lanceolate, apically subacute anthers; style filiform c. $0.2 \mathrm{~cm}$; stigma capitates. Fruits up to 1 x $0.3 \mathrm{~cm}$, embedded in calyx tube, oblong with cuneate base.

Specimen examined: K20459; Mt. Harriet, South Andamans, India; S. P. Mathew 20459K; 13 December 1989.

Flowering \& Fruiting: November to January

\section{Acknowledgements}

The first author would like to thank P. G. Latha (Director - JNTBGRI) for encouragements and 
second author express his sincere thanks to Paranjit Singh (Director - BSI, Kolkata) for encouragements. The authors are also thankful to V. Sampathkumar (Indian Liaison Officer at Kew herbarium) for sharing herbarium details on this species at Kew. Finally we would like to thank James L. Reveal (Cornell University USA) for editing the manuscript.

\section{Literature cited}

King, G., 1900. Materials for a flora of Malay Peninsula, Journal of Asiatic Society of Bengal 69: 1-87.

Lakshminarasimhan, P. and P. S. N. Rao, 1996. A supplementary list of angiosperms recorded (1983-1993) from Andaman-Nicobar Islands. Journal of Economic and Taxonomic Botany, 20: 175-185.

Lakshminarasimhan, P., S. Gantait, L. Rasingam, and S. Bandyopadhyay, 2011. Bibilography and abstracts of papers on flora of Andaman \& Nicobar Islands. Botanical Survey of India, Ministry of Environment \& Forests, Howrah.

Mathew, S. P., 1998. A supplementary report on the flora and vegetation of the Bay Islands, India. Journal Economic and Taxonomic Botany 22: 249-272.

Pandey, R. P. and P. G. Diwakar, 2008. An integrated check-list flora of Andaman and Nicobar Islands, India. Journal of Economic and Taxonomic Botany, 32: 403-50.

VasudevaRao, M. K., 1986. A preliminary report on the angiosperms of Andaman-Nicobar Islands. Journal of Economic and Taxonomic Botany, 8: 107-184.

Submitted: 12 March 2013, Accepted: 09 April 2013 Sectional Editor: James L. Reveal

Sam P. Mathew ${ }^{1} \&$ P Laksminarashimhan ${ }^{2}$

${ }^{1}$ Jawaharlal Nehru Tropical Botanic Garden \& Research Institute, Thiruvananthapuram 695562, Kerala, India

E-mail: sampmatthew@ rediffmail.com

${ }^{2}$ Botanical Survey of India, Central National Herbarium, Botanic Garden PO, Kolkata 711103, West Bengal, India E-mail: lakshminarsimhanp@yahoo.co.in 